\title{
The influence of previous protein or energy restriction of young pigs on their daily gain composition
}

\author{
G. Skiba, H. Fandrejewski, St. Raj and D. Weremko
}

\author{
The Kielanowski Institute of Animal Physiology and Nutrition, \\ Polish Academy of Sciences \\ 05-110 Jablonna, Poland
}

(Received 6 November 2001; revised version 22 April 2002; accepted 9 May 2002)

\begin{abstract}
The influence of previous feed (energy) or protein restriction on daily gain composition was investigated on 78 pigs. Group E pigs from 15 to $25 \mathrm{~kg}$ (restriction period) consumed $40 \%$ less feed (energy) daily, group P pigs, $40 \%$ less protein as compared with control pigs, group C. From 25 to 70 $\mathrm{kg}$ (realimentation period) all pigs were fed dicts with a low (12.4 MJ ME) or high (13.2 MJ ME) energy content on a restricted feeding level or ad libitum. Animals were slaughtered at $15 \mathrm{~kg}(\mathrm{n}=4), 25$ $\mathrm{kg}(\mathrm{n}=12)$ and $70 \mathrm{~kg}(\mathrm{n}=66)$ and their bodies were analysed for protein, fat, ash and water content. During restriction the $P$ and $E$ animals grew more slowly than the $C$ pigs ( 370 and 247 vs $513 \mathrm{~g} /$ day, $\mathrm{P}<0.01$ ) and deposited less protein daily in their bodies (39 and 37 vs $72 \mathrm{~g}, \mathrm{P}<0.01$ ). Daily fat deposition differed between groups of pigs $(\mathrm{P}<0.01)$ and was the lowest in the $E(13 \mathrm{~g})$ and the highest in the $P$ pigs $(95 \mathrm{~g})$. During realimentation $(25.70 \mathrm{~kg})$ the $P$ pigs deposited more protein daily $(\mathrm{P}<0.01)$ compared with the $\mathrm{C}$ and $\mathrm{E}$ pigs ( 140 vs 132 and $132 \mathrm{~g}$ ). Daily fat deposition was the lowest $(\mathrm{P}<0.05)$ in the $\mathrm{P}$ and the highest in the E pigs. The $\mathrm{P}$ and $\mathrm{E}$ pigs deposited more protein daily in the entrails than the $\mathrm{C}$ animals ( 23 and 22 vs $20 \mathrm{~g}$, respectively; $\mathrm{P}<0.05$ ). The $\mathrm{P}$ pigs tended to deposit more, but the E pigs less protein in the carcass daily as compared with the $C$ pigs $(117,110$ and $112 \mathrm{~g}$, respectively; $\mathrm{P}<0.07$ ). It seems that a different compensatory response of pigs previously underfed for protein or feed intake results from the different physiological statc of their bodies at the end of restriction. A compensatory response was directed to that part of the body (body component) whose growth had been reduced the most during previous restriction.
\end{abstract}

KEY WORDS: pigs, compensatory growth, gain composition 


\section{INTRODUCTION}

The results of previous work by Skiba et al. (2001) indicated that pigs restricted for protein or feed (energy) intake differed in body composition at the end of restriction as compared with control pigs. The main differences concerned a size of the entrails as well as fat and protein stores. The pigs that consumed less feed had a lower mass of entrails and lower fat but higher protein stores, whereas those that consumed a low protein diet had higher fat and lower protein stores and their entrails did not differ from control pigs. During the subsequent period of growth when the diet was adequate to pigs' requirements they were able to compensate their anatomical (size of entrails) and chemical body composition. Thus, at the end of the study the protein and fat contents in the body as well as the size of entrails did not differ significantly between control pigs and those previously underfed for protein or feed (energy).

Data from the literature on the composition of compensatory gain show that it differs from control animals in previously underfed animals. The main differences concern higher protein deposition in the body of previously underfed animals. However, data on the amount of fat deposition are ambiguous (e.g., Stamataris et al., 1991; de Greef, 1992; Bikker, 1994). It is also not clear if higher (compensatory) protein deposition takes place in the carcass or in the entrails. The reason for these discrepancies can be differences in the kind of previous restriction (feed or protein) closely connected with body composition at the end of this period. Thus, the results of studies done so far cannot be compared directly. Moreover, no simultaneous comparisons of the gain composition of pigs previously underfed for protein or feed intake on similar diets and at similar feeding levels have been found in the literature.

The aim of this study was to test the hypothesis that daily gain composition during compensatory growth depends on previous feed or protein underfeeding.

\section{MATERIAL AND METHODS}

A detailed description of animals, feed values and experimental design was given in a previous paper (Skiba et al., 2001). In summary, the procedure was as follows: during the restriction period (from 15 to $25 \mathrm{~kg}$ ) the $\mathrm{P}$ pigs were underfed for protein ( $40 \%$ less compared with the controls, $C$ ) while the E group was underfed for feed (energy) intake ( $40 \%$ less compared with C). During the subsequent realimentation period all of the pigs were fed diets with a low (12.4 MJ ME - the $\mathrm{L}$ diet) or high (13.2 MJ ME - the $\mathrm{H}$ diet) energy content on a restricted feeding level $(\mathrm{R})$ or ad libitum $(\mathrm{A})$. 
The procedure applied to estimate the daily gain composition was based on the comparative slaughter method described by Kotarbińska (1971). Pigs were slaughtered at the beginning of the experiment $(15 \mathrm{~kg}, \mathrm{n}=4)$, at the end of the restriction period ( $25 \mathrm{~kg}$, four from each group, $n=12)$ and at the end of the realimentation period $(70 \mathrm{~kg}, \mathrm{n}=66)$. After slaughter, the carcass, entrails and hair were analysed for protein, fat, ash and water content (AOAC, 1994). For calculation purposes, the chemical composition and weight of the hair were included in the carcass. The results presented in this study on daily gain of protein, fat, ash and water in the pigs' bodies werc calculated by subtraction of initial (at 15 and $25 \mathrm{~kg}$ ) from final (at 25 and $70 \mathrm{~kg}$ ) contents of these components in the body.

Statistical analyses were performed by three-way analysis of variance ANOVA using Statgraphics version 6.0 Plus software.

\section{RESULTS}

\section{Restriction phase}

Protein as well as feed (energy) restriction changed the composition of daily gain of pigs (Table 1). The $\mathrm{P}$ and $\mathrm{E}$ pigs deposited similar amounts of protein daily in the body ( 39 and $37 \mathrm{~g}$, respectively) but significantly $(\mathrm{P}<0.01)$ less than the control, $\mathrm{C}$ pigs ( $66 \mathrm{~g})$. The $\mathrm{P}$ pigs deposited daily more $(\mathrm{P}<0.01)$ while the $\mathrm{E}$ less fat in the body as compared with the $C$ group ( 95 and $13 \mathrm{vs} 66 \mathrm{~g} /$ day, respectively). Daily water deposition differed $(\mathrm{P}<0.01)$ between groups and amounted 271,165 and $145 \mathrm{~g} /$ day, respectively in the $\mathrm{C}, \mathrm{P}$ and $\mathrm{E}$ pigs.

The fat:protein ratio in the daily gain of the P pigs was almost seven times higher that compared in the E animals ( $2.47 \mathrm{vs} 0.36$ ). Water and ash to protein ratios in the daily gain of pigs did not differ significantly between groups of animals (Table 1).

\section{Realimentation phase $(25-70 \mathrm{~kg})$}

In comparison with the $\mathrm{R}$ pigs the A pigs deposited daily more $(\mathrm{P}<0.01)$ protein (141 vs $128 \mathrm{~g}$ ) as well as fat (199 vs $164 \mathrm{~g}$ ) and water (528 vs $465 \mathrm{~g}$; Table 2).

The pigs fed the $\mathrm{H}$ diet deposited more $(\mathrm{P}<0.01)$ protein $(142 \mathrm{vs} 126 \mathrm{~g})$ and water ( $536 \mathrm{vs} 458 \mathrm{~g}$ ) daily compared with animals fed the $\mathrm{L}$ diet but fat accretion in both groups was similar (182 vs $181 \mathrm{~g})$.

The $\mathrm{P}$ pigs deposited more $(\mathrm{P}<0.05)$ protein daily compared with the $\mathrm{C}$ and $\mathrm{E}$ animals ( 140 vs 132 and $132 \mathrm{~g} /$ day, respectively). Daily fat deposition differed $(\mathrm{P}<0.05)$ between groups and amounted 179 (C pigs), 170 (P pigs) and $197 \mathrm{~g}$ (E pigs).

The pigs having free access to feed $(\mathrm{A})$ and those fed the high energy diet $(\mathrm{H})$ deposited more $(\mathrm{P}<0.01)$ protein in the carcass as compared with animals fed 
TABLE 1

Average daily gain, daily gain composition, and ratios of fat:protein, water:protein, ash:protein in daily gain of the pigs growing from 15 to $25 \mathrm{~kg}$

\begin{tabular}{lcccc}
\hline & \multicolumn{3}{c}{ Group } & s.e. \\
\cline { 2 - 4 } & \multicolumn{1}{c}{$\mathrm{C}^{\mathrm{C}}$} & $\mathrm{P}^{2}$ & $\mathrm{E}^{3}$ & \\
\hline Average daily gain, $\mathrm{g}$ & $513^{\mathrm{C}}$ & $370^{\mathrm{B}}$ & $247^{\mathrm{A}}$ & 3.5 \\
& & & & \\
& Composition of daily gain, & & 1.05 \\
Protein & $66^{\mathrm{B}}$ & $39^{\mathrm{A}}$ & $37^{\wedge}$ & 1.49 \\
Fat & $72^{\mathrm{B}}$ & $95^{\mathrm{C}}$ & $13^{\mathrm{A}}$ & 5.77 \\
Water & $271^{\mathrm{C}}$ & $165^{\mathrm{B}}$ & $145^{\mathrm{A}}$ & 0.62 \\
Ash & $12^{\mathrm{B}}$ & $8^{\mathrm{AB}}$ & $5^{\mathrm{A}}$ & \\
& & & & \\
Fat:protein & Ratios betwcen gain components & & $0.35^{\wedge}$ & 0.06 \\
Water:protein & $1.09^{\mathrm{B}}$ & $2.44^{\mathrm{C}}$ & 3.92 & 0.16 \\
Ash:protein & 4.11 & 4.23 & 0.135 & 0.003 \\
\hline
\end{tabular}

ABC $\mathrm{P}<0.01$

${ }^{\prime} \mathrm{C}$ - control group

${ }^{2} \mathrm{P}$ - less protein intake during restriction period (15-25 $\mathrm{kg} \mathrm{BW}$ )

${ }^{3} \mathrm{E}$ - less feed (energy) intake during restriction period (15-25 $\left.\mathrm{kg} \mathrm{BW}\right)$

at a restricted level $(\mathrm{R})$ and those fed a low energy diet (L) (117 and $119 \mathrm{vs} 108$ and $106 \mathrm{~g} /$ day) (Table 2).

The $\mathrm{P}$ and $\mathrm{E}$ pigs deposited on average more $(\mathrm{P}<0.05)$ protein in the entrails as compared with the $\mathrm{C}$ animals ( 23 and 22 vs $20 \mathrm{~g} / \mathrm{day}$ ) whereas differences in protein deposition in the carcass were insignificant $(\mathrm{P}<0.07)(117$ and 110 vs $112 \mathrm{~g} /$ day, respectively).

Daily water deposition ranged from $483 \mathrm{~g} /$ day (the E pigs) to $491 \mathrm{~g} / \mathrm{day}$ (the $\mathrm{C}$ pigs) and $516 \mathrm{~g} /$ day (the $\mathrm{P}$ pigs) but a significant difference $(\mathrm{P}<0.05)$ was found only between the $\mathrm{P}$ and $\mathrm{E}$ pigs (Table 2).

The fat:protein ratio of the pigs fed ad libitum (A) (1.41) and those fed a diet with a low energy content $(\mathrm{L})(1.43)$ was higher $(\mathrm{P}<0.05)$ compared with pigs fed at a restricted feeding level (R) (1.29) as well as those fed on a high energy $\operatorname{diet}(\mathrm{H})$ (1.27). The fat:protein ratio was lower in the $\mathrm{P}$ and higher $(\mathrm{P}<0.05)$ in the $\mathrm{E}$ pigs as compared with control animals ( 1.19 and 1.49 vs 1.36 , respectively).

The water:protein ratio was higher $(\mathrm{P}<0.01)$ in the pigs fed ad libitum as compared with those fed at the restricted level ( $3.75 \mathrm{vs} 3.64)$.

Pigs fed the low energy diet had a lower $(\mathrm{P}<0.01)$ ash:protein ratio than pigs fed the high energy mixture $(0.150$ vs 0.176$)$. 


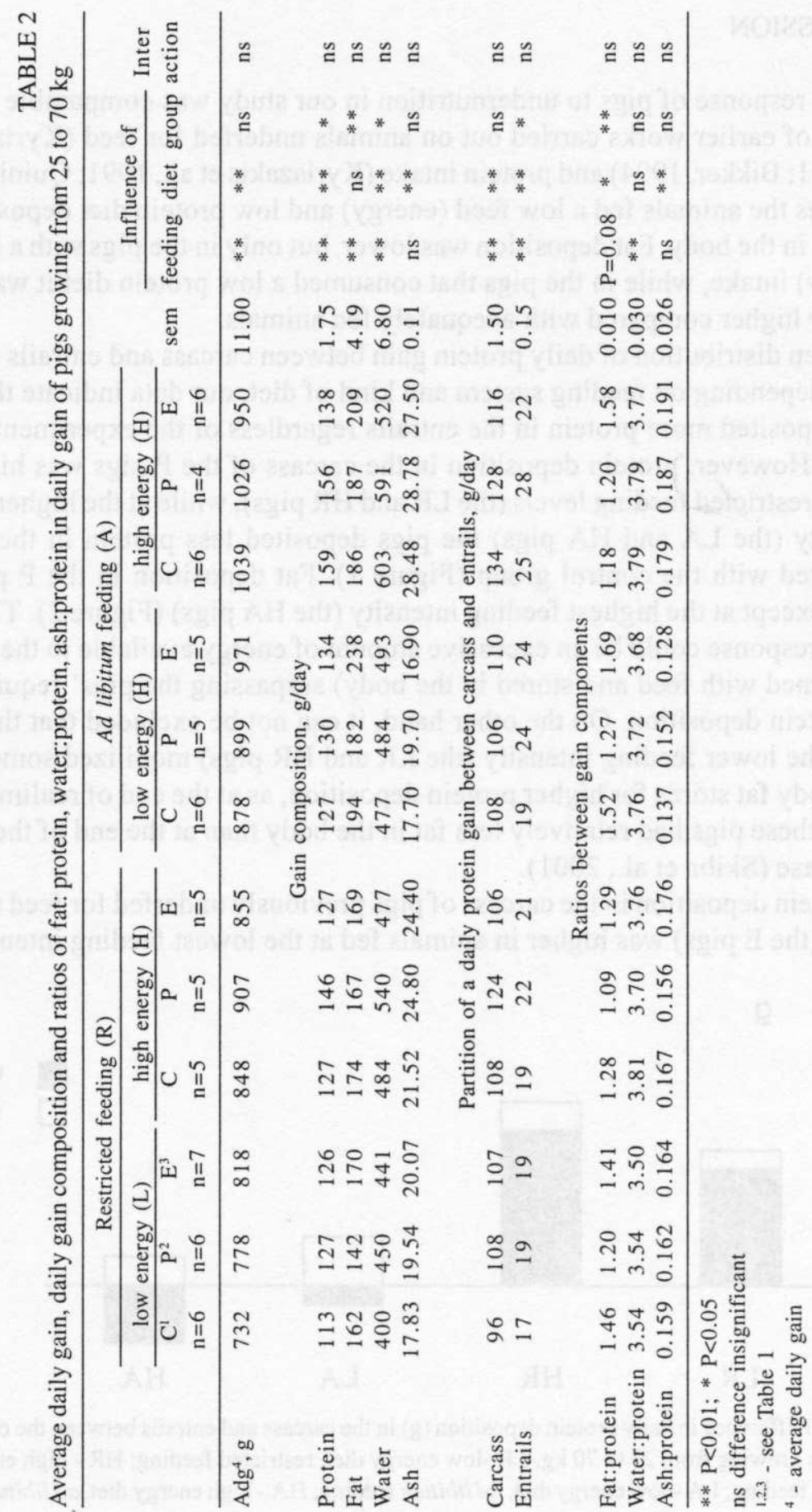




\section{DISCUSSION}

The response of pigs to undernutrition in our study was comparable with the results of earlier works carried out on animals underfed for feed (Kyriazakis et al., 1991; Bikker, 1994) and protein intake (Kyriazakis et al., 1991; Quiniou et al., 1995 ) as the animals fed a low feed (energy) and low protein diet deposited less protein in the body. Fat deposition was lower, but only in the pigs with a low feed (energy) intake, while in the pigs that consumed a low protein diet it was considerably higher compared with adequately fed animals.

When distribution of daily protein gain between carcass and entrails is considered depending on feeding system and kind of diet, our data indicate that the $\mathrm{P}$ pigs deposited more protein in the entrails regardless of the experimental treatments. However, protein deposition in the carcass of the P pigs was higher but only at restricted feeding levels (the LR and HR pigs), while at the higher feeding intensity (the LA and HA pigs) the pigs deposited less protein in the carcass compared with the control group (Figure 1). Fat deposition in the $\mathrm{P}$ pigs was lower except at the highest feeding intensity (the HA pigs) (Figure 2). The cause of this response could be an excessive amount of energy available to the animals (consumed with feed and stored in the body) surpassing the pigs' requirements for protein deposition. On the other hand, it can not be excluded that the P pigs fed at the lower feeding intensity (the LR and HR pigs) mobilized some part of their body fat stores for higher protein deposition, as at the end of realimentation period these pigs had relatively less fat in the body than at the end of the restriction phase (Skiba et al., 2001).

Protein deposition in the carcass of pigs previously underfed for feed (energy) intake (the E pigs) was higher in animals fed at the lowest feeding intensity (the

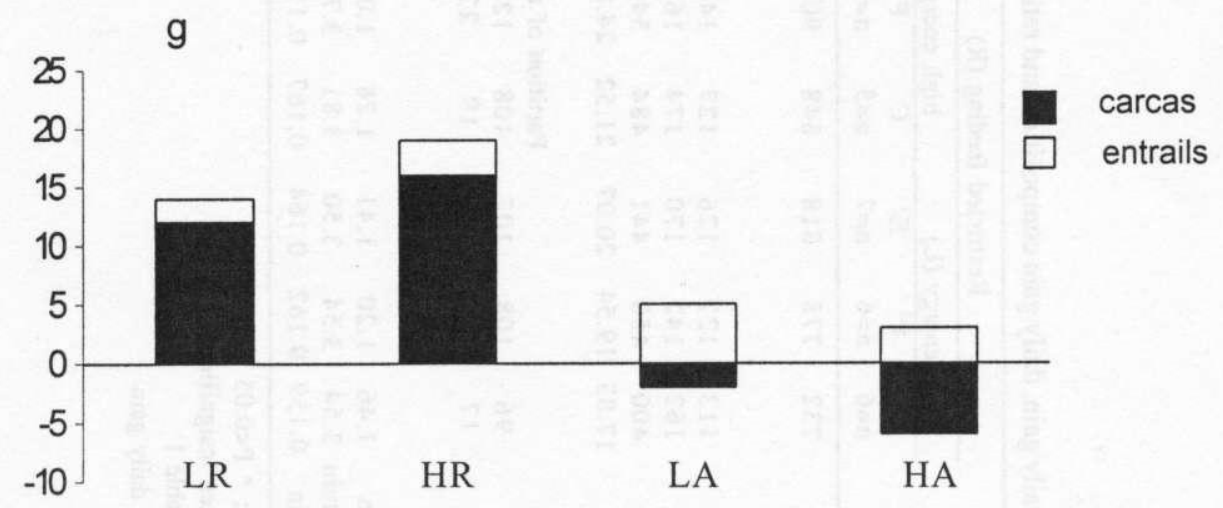

Figure 1. Difference in daily protein deposition $(\mathrm{g})$ in the carcass and entrails between the control and the P pigs growing from 25 to $70 \mathrm{~kg}$. LR -low energy diet, restricted feeding; HR - high energy diet, restricted feeding; LA - low energy diet, ad libitum feeding; HA - high energy diet, ad libitum feeding 


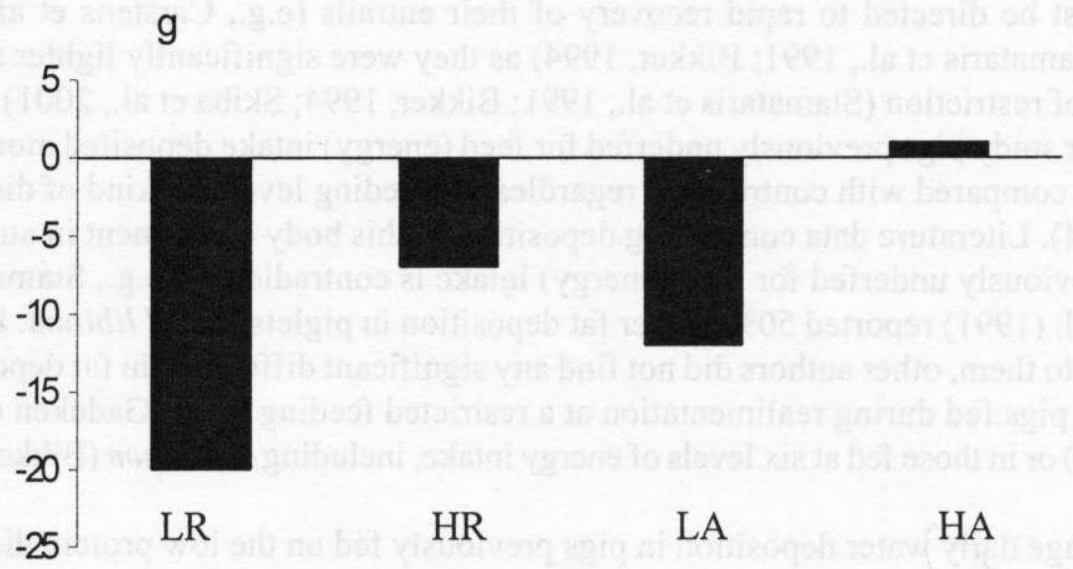

Figure 2. Difference in daily fat deposition in the empty body $(\mathrm{g})$ between control and the P pigs growing from 25 to $70 \mathrm{~kg}$. LR - low energy diet, restricted feeding; HR - high energy diet, restricted feeding; LA - low energy diet, ad libitum feeding; HA - high energy diet, ad libitum feeding

LR pigs), whereas, at the highest feeding intensity (the HA pigs) was low. The remaining pigs from this group fed at the intermediate level (the HR and LA pigs) deposited a similar amount of protein in the carcass compared with control pigs (Figure 3). However, protein deposition in the entrails of the E pigs was greater or equal (at the highest feeding intensity) to control pigs. This shows that pigs previously underfed for feed (energy) intake prefer protein accretion in the entrails to the carcass. It also shows that the compensatory protein gain in these

g

carcass

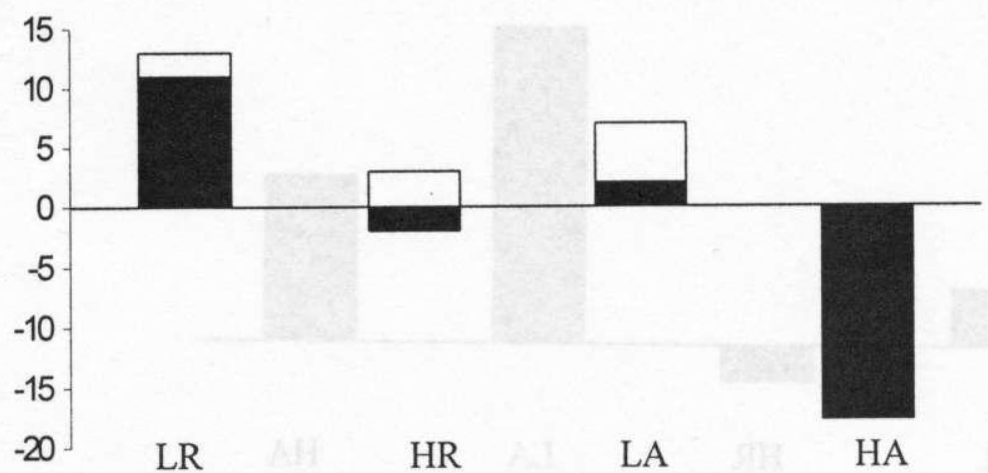

Figure 3. Difference in daily protein deposition ( $\mathrm{g}$ ) in the carcass and entrails between control and the E pigs growing from 25 to $70 \mathrm{~kg}$. LR - low energy diet, restricted feeding; HR - high energy diet, restricted feeding; LA - low energy diet, ad libitum feeding; HA - high energy diet, ad libitum feeding 
pigs must be directed to rapid recovery of their entrails (e.g., Carstens et al., 1991; Stamataris et al., 1991; Bikker, 1994) as they were significantly lighter at the end of restriction (Stamataris et al., 1991; Bikker, 1994; Skiba et al., 2001).

In our study pigs previously underfed for feed (energy) intake deposited more fat daily compared with control pigs regardless of feeding level and kind of diet (Figure 4). Literature data concerning deposition of this body component in animals previously underfed for feed (energy) intake is contradictory: e.g., Stamataris et al. (1991) reported 50\% higher fat deposition in piglets fed ad libitum. In contrast to them, other authors did not find any significant difference in fat deposition in pigs fed during realimentation at a restricted feeding level (Gadeken et al., 1980) or in those fed at six levels of energy intake, including ad libitum (Bikker, 1994).

Average daily water deposition in pigs previously fed on the low protein diet was significantly higher than in the pigs previously fed the low amount of feed (energy), and slightly higher than in the control pigs. But lack of differences in the water:protein ratio (in the empty body) between control and previously underfed pigs indicates that compensatory protein gain found in the $\mathrm{P}$ pigs is not associated with enhanced water deposition, which was pointed out earlier by some authors (e.g., Carstens et al., 1991).

The lowest fat:protein ratio in the pigs previously fed a low protein diet (group P) was caused by lower fat and higher protein deposition by these pigs; this was also pointed out in earlier studies (e.g., de Greef, 1992). However, the pigs that previously consumed the low amount of feed (energy) had the worst fat:protein ratio as they deposited the highest amount of fat. Contradictory results were

g

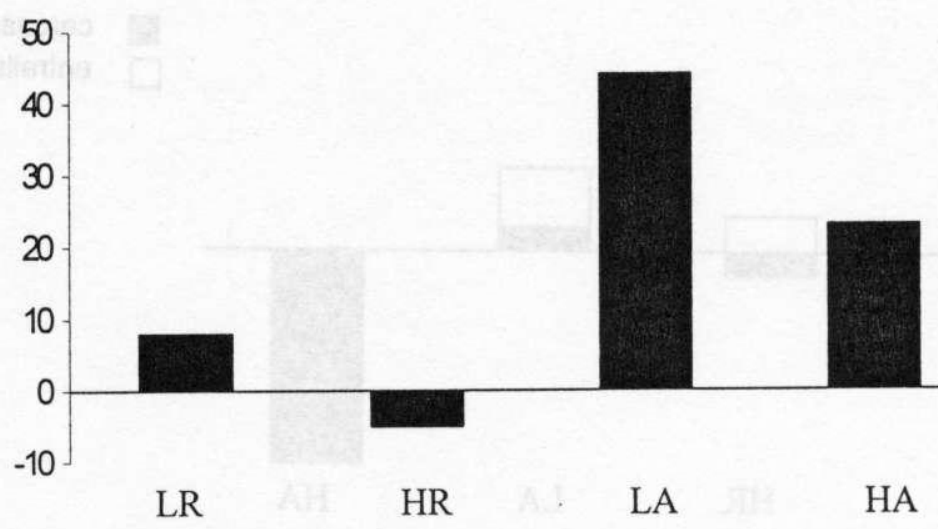

Figure 4. Difference in daily fat deposition (g) in the empty body between control and the E pigs growing from 25 to $70 \mathrm{~kg}$. LR - low energy diet, restricted feeding; HR - high energy diet, restricted feeding; LA - low energy diet, ad libitum feeding; HA - high energy diet, ad libitum feeding 
given by Bikker (1994) who did not find any influence of previous low feed intake on the fat:protein ratio in pigs grown from 45 to $85 \mathrm{~kg}$.

A lower ash:protein ratio in pigs fed a diet with the low energy (L) as compared with those fed the high energy $\operatorname{diet}(\mathrm{H})$ resulted from the lower availability of mineral components in the $\mathrm{L}$ diet. It was based on rapeseed meal (as the main source of protein), which contains a very high phosphorus and calcium density, but the biological availability of these minerals is very low (NRC, 1998).

\section{CONCLUSIONS}

It seems that the different compensatory response of pigs previously underfed for protein or feed (energy) intake resulted from the different physiological state of their organism at the end of restriction. During subsequent realimentation a compensatory response was directed to the part of the body (body component) which growth had been reduced the most during restriction. In the case of pigs previously underfed for protein, body protein stores were strongly reduced, so during realimentation this body component was restored first of all, even at the cost of fat deposition. However, fat reserves in the body as well as the weight of entrails of the pigs previously restricted for feed (energy) intake were so low that compensatory protein gain was allocated in the viscera, the remaining feed components (mainly energy) consumed with feed were directed to repletion of body fat reserves.

\section{REFERENCES}

AOAC, 1994. Association of Official Analytical Chemists, Officials Methods of Analysis. 15th Edition. Washington, DC

Bikker P., 1994. Protein and lipid accretion body components of growing pigs: effects of body weight and nutrient intake. PhD-Thesis. Wageningen Agricultural University, Wageningen (The Netherlands), pp. 1-203

Carstens G.E., Johnson D.E., Ellenberger M.A., Tatum J.D., 1991. Physical and chemical components of the empty body during compensatory growth in beef steers. J. Anim. Sci. 69, 325 I-3264

de Greef K.H., 1992. Prediction of production. Nutrition induced tissue partitioning in growing pigs. PhD-Thesis, Wageningen Agricultural University, Wageningen (The Netherlands), pp. 1-117

Gadeken D., Bohme H., Oslage H.J., 1980. Restriction of feed intake and compensatory growth responses in pigs. Proceedings of the $9^{\text {th }}$ Symposium on Energy Metabolism, EAAP Publication No. 26, pp. $407-410$

Kotarbińska M., 1971. The chemical composition of the body in growing pigs. Rocz. Nauk. rol. B-93, 129-135

Kyriazakis I., Stamataris C., Emmans G.C., Whittemore C.T., 1991. The effects of food protein content on the performance of pigs previously given foods with low or moderate protein content. Anim. Prod. 52, 165-174 
NRC, 1998. Nutrient Requirements of Swine. 10 $10^{\text {th }}$ revised Edition. National Academy Press, Washington $\mathrm{DC}$

Quiniou, M., Dubois S., Noblet J., 1995. Effect of dietary crude protein level on protein and energy balances in growing pigs. Comparison of two measurement methods. Livest. Prod. Sci. 41, 51-61

Skiba G., Fandrcjewski H., Raj St., Weremko D., 2001. The performance and body composition of growing pigs during protein or energy deficiency and subsequent realimentation. J. Anim. Feed Sci. 10,633-647

Stamataris C., Kyriazakis I., Emmans G.C., 1991. The performance and body composition of young pigs following a period of growth retardation by food restriction. Anim. Prod. 53, 373-38I

\section{STRESZCZENIE}

\section{Wplyw uprzedniego ograniczenia pobrania bialka lub energii na sklad przyrostu dziennego rosnących świn}

Badano wpływ ograniczenia dziennego pobrania paszy (energii) lub białka na skład przyrostu dziennego świń w okresie późniejszym. W okresie restrykcji (15-25 kg) świniom podawano o $40 \%$ mniej paszy (energi) - grupa E lub o $40 \%$ mniej bialka - grupa $P$, w porównaniu ze zwierzętami kontrolnymi (grupa C). W okresic realimentacji (25-70 kg) wszystkie świnie żywiono paszą z niską (12.4 MJ ME - dieta L) lub wysoką (13.2 MJ ME - dicta H) zawartością energii systemem dawkowanym (R) lub do woli (A). Przyrost chemicznych składników ciała świń w okrcsie restrykcyjnym i realimentacji oznaczono metodą ubojową. Zwierzęta ubijano przy $15(\mathrm{n}=4), 25(\mathrm{n}=12)$ i $70 \mathrm{~kg}$ $(n=66)$. W okresie restrykcyjnym świnie grup P i E rosły wolniej niż zwierzęta kontrolne ( 370 i 247 vs $513 \mathrm{~g} / \mathrm{dzjen}, \mathrm{P}<0,01$ ) oraz odkładały mniej bialka w ciele ( $39 \mathrm{i} 37 \mathrm{vs} 72 \mathrm{~g} /$ dzień, $\mathrm{P}<0,01$ ). Dzienne odłożenie tłuszczu różniło się między grupami $(\mathrm{P}<0,01)$ : było najmniejsze $\mathrm{u}$ świń grupy $\mathrm{E}(13 \mathrm{~g})$, największe u zwierząt grupy $\mathrm{P}(95 \mathrm{~g})$. W okresic realimentacji świnie grupy $\mathrm{P}$ odkładały dziennie więcej białka niż zwierzęta grup C i E (140 vs 132 i $132 \mathrm{~g}$ ). Dzienne odłożenie tłuszczu było najmniejsze $(P<0,05)$ u świń grupy $P$, największe u zwierząt grupy E. Świnie grup $P$ i E odkładaly dziennie więcej $(P<0,05)$ białka we wnętrznościach niż świnie grupy $\mathrm{C}(23$ i 22 vs $20 \mathrm{~g})$. Dzienne odłożenie białka w tuszy nie różniło sic statystycznie między zwierzętami (117, 110 i 112 g, odpowiednio w grupie P, E i C). Stwierdzono, że skład przyrostu dziennego zależał od sposobu uprzedniego niedożywiania. Kompensacja wzrostu dotyczyła głównie tych partii ciała (lub składnika), których wzrost był najbardziej spowolniony w okresie restrykcyjnym. 